How to cite: Kaya, Y.Z., Taşar, B. (2019) Evapotranspiration Calculation for South Carolina, USA and Creation Different ANFIS Models for ET Estimation. 2019 "Air and Water - Components of the Environment" Conference Proceedings, Cluj-Napoca, Romania, p. 217-224, DOI: 10.24193/AWC2019_22.

\title{
EVAPOTRANSPIRATION CALCULATION FOR SOUTH CAROLINA, USA AND CREATION DIFFERENT ANFIS MODELS FOR ET ESTIMATION
}

\author{
Yunus Ziya KAYA ${ }^{1}$ 凹 Bestami TAŞAR
}

DOI: 10.24193/AWC2019_22

\begin{abstract}
Evapotranspiration (ET) is a significant parameter of hydrologic cycle. Accurate calculation or estimation of ET is an important issue for water management engineers and irrigation engineers. However, it is not always so simple to calculate ET because of the direct and indirect effects. In this study, Daily ET is calculated by using Penman FAO 56 standard equation which is developed by U.S. Food and Agricultural Organization-FAO. 1416 daily meteorological data is taken from USGS (United States of Geological Survey) South Carolina observation station. Data set is divided as training and test set randomly and test set is existed from 233 daily data. Daily Air Temperature, Wind Speed, Relative Humidity and Solar Radiation meteorological variables are used in adaptive neuro fuzzy inference system (ANFIS) model creation process. Three different models are created and results are compared with each other.
\end{abstract}

Keywords: Evapotranspiration, Estimation, ANFIS, Empirical Equation

\section{INTRODUCTION}

Evapotranspiration (ET) is defined as the combination of transpiration and evaporation. It is one of the main part of hydrological cycle. Understanding hydrological cycle has critical importance for hydraulic and irrigation engineers especially in dry sessions. It is important to calculate or estimate evapotranspiration loss to make future projections based on water use planning. However, it is not so clear and easy to estimate ET directly because of the effects of direct and indirect variables. In the past decade, scientists used different methods to estimate ET such as calibration of empirical equations and soft computing techniques (Chen, 2012; Dogan, 2009; Kaya et al., 2017, 2016b, 2016a; Kisi, 2008; Kişi, 2006; Kumar et al., 2011; Mamak et al., 2017; Pal and Deswal, 2009; Ünes et al., 2017).

These soft computing techniques are also in use for further hydrological cases because of the their abilities on making estimations on nonlinear cases (Demirci et

\footnotetext{
1 Osmaniye Korkut Ata University, Eng. Faculty, Civil Eng Department, TURKEY yunuszkaya@osmaniye.edu.tr

2 Iskenderun Technical University, Eng. Faculty, Civil Eng Department, TURKEY bestami.tasar@iste.edu.tr
} 
al., 2018a; Demirci et al., 2018b; Demirci and Baltaci, 2013; Demirci et al., 2015a; Kaya et al., 2018; Kim and Kim, 2008; Kutyłowska, 2016; Talei et al., 2013; Taşar et al., 2017; Taşar et al., 2018; Uneş F., 2010a; Uneş F., 2010b; Unes and Demirci, 2015; Üneş et al., 2015a, 2015b; Üneş et al., 2018a; Üneş et al., 2018b; Üneş et al., 2018c; Yu et al., 2006; Uneş et al., 2013; Uneş et al., 2017; Demirci et al., 2015b; Demirci et al., 2016; Demirci et al., 2016).

In this paper, authors used Adaptive Neuro-Fuzzy Inference System (ANFIS) soft computing technique to estimate daily ET values of South Carolina, USA. Data set contains Wind Speed (U), Relative Humidity (RH), Air Temperature (T) and Solar Radiation (SR) meteorological records. Data set is belonging to United States of Geological Survey (USGS) and it has 1416 daily measurements. Data set is divided 1183 days as training and 233 days as test set randomly.

Three different ANFIS models are created to make estimations on ET and results are compared with each other by using correlation coefficient, Mean Square Error (MSE), and Mean Absolute Error statistics.

\section{METHODOLOGY}

\subsection{Adaptive neuro-fuzzy inference system}

Adaptive neuro-fuzzy inference system (ANFIS) uses the learning ability and parallel calculation of neural networks and benefits of fuzzy logic together so it is a hybrid artificial intelligence method.

ANFIS model is built up by Jang (Jang, 1993) and this model uses Sugeno\&Kank type (Takagi and Sugeno, 1985) fuzzification system and hybrid learning algorithm. Adaptive networks occur from directly connected nodes and each node represents a transaction unit. The structure of an ANFIS model consists of 5 different layers. For further information about ANFIS readers are referred to (Jang, 1993).

ANFIS model 1 is created by using all four SR, T, RH, $U$ parameters as input and ET is coded as output. ANFIS model 2 is creating by using SR, T, RH parameters as input and ET is coded as output. And for the ANFIS model number 3 only SR and T parameters are chosen as inputs and ET as output.

\subsection{Penman FAO 56 Equation}

SR, AT, RH, U daily meteorological parameters are needed to calculate daily ET using Penman FAO 56 equation. Equation is given as below (Jensen et al., 1990);

$$
E T=\left(\frac{\Delta}{\Delta+Y}\right) R_{n}+\frac{\gamma}{\Delta+Y}\left[15.36\left(1+0.0062 u_{2}\right)\left(e_{W}-e_{⿷}\right)\right]_{\lambda}^{\frac{1}{\lambda}}
$$

where

$\gamma$ is the psychometric constant,

$\Delta$ is the slope of the vapour pressure curve,

$\mathrm{R}_{\mathrm{n}}$ is the net radiation,

$\mathrm{u}_{2}$ is the wind speed at $2 \mathrm{~m}$ height,

$\mathrm{e}_{\mathrm{w}}$ is the saturation vapour pressure,

$\mathrm{e}_{\mathrm{a}}$ is the actual vapour pressure and

$\lambda$ is the latent heat of vaporization in equation. 
This equation is approved as standard equation by U.S. Food and Agricultural Organization-FAO. Therefore, it is used to calculate ET for mentioned area and ANFIS model's results are compared with these calculated values

\section{RESULTS}

Three different ANFIS model distribution graphs and scatter charts are given separately to see the performance of the models.

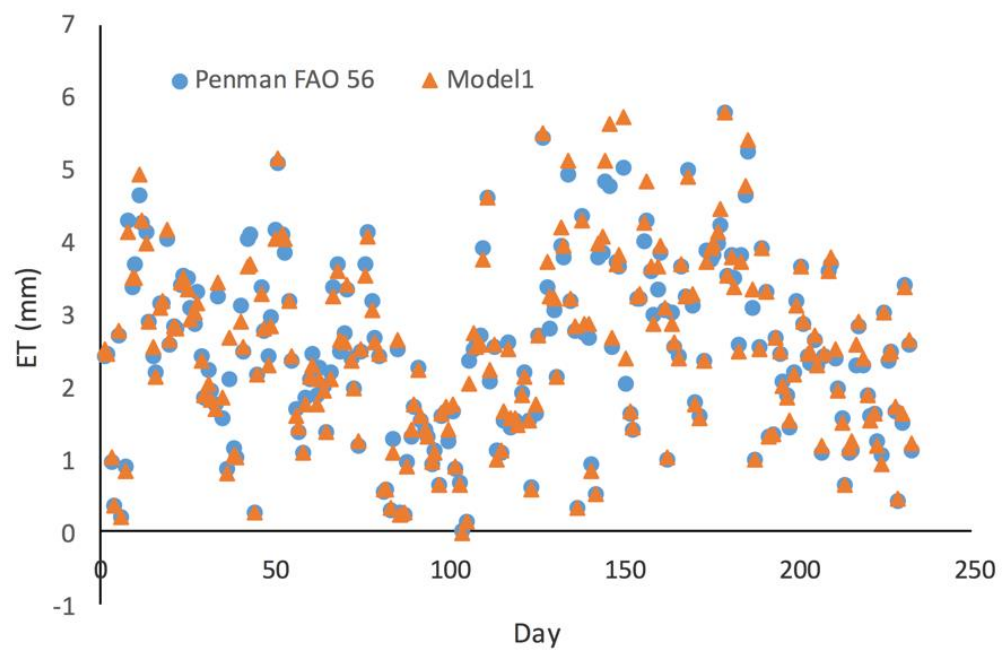

Fig. 1. Distribution graph of Model 1

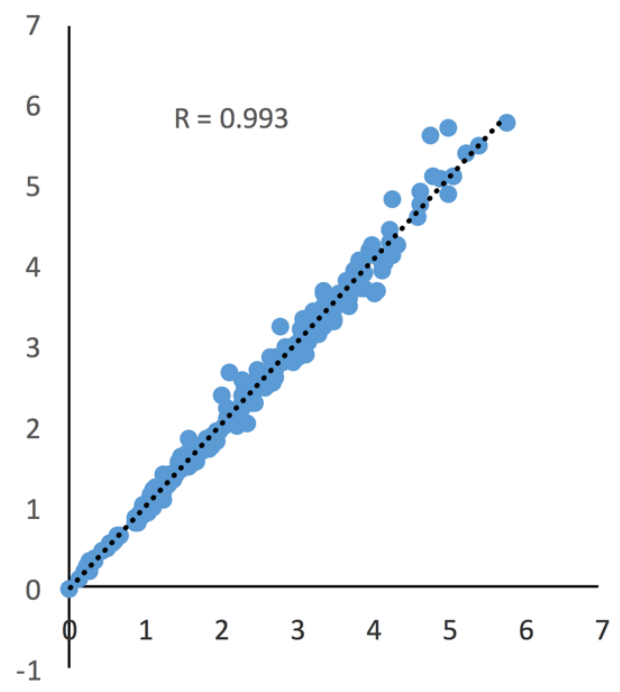

Fig. 2. Scatter chart of Model 1 
Distribution graph and scatter chart belonging to model 1 are given with Figure 1 and Figure 2 respectively. This model uses SR, T, RH, U parameters as input and as it is seen it gives super close results with Penman FAO 56 empirical equation.

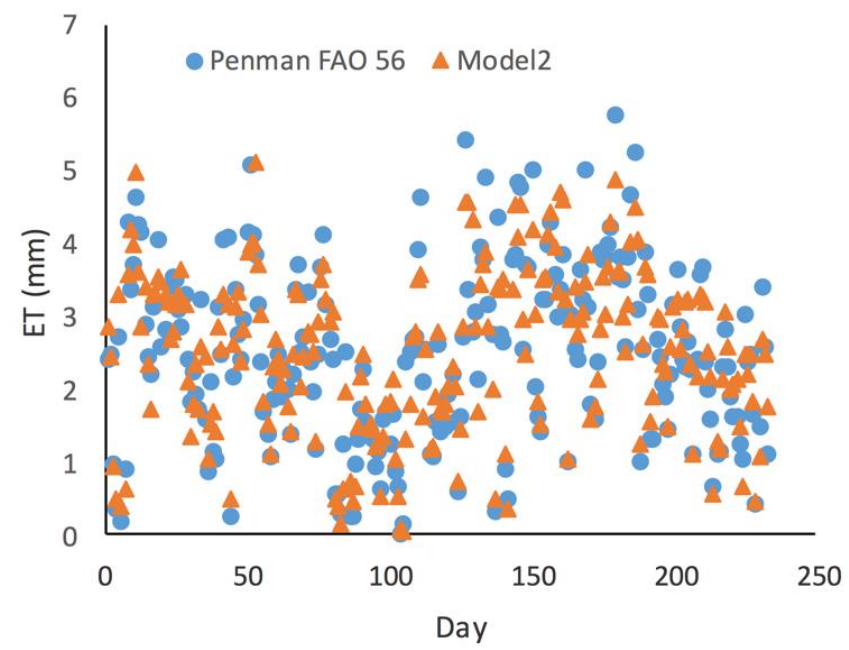

Fig. 3. Distribution graph of Model 2

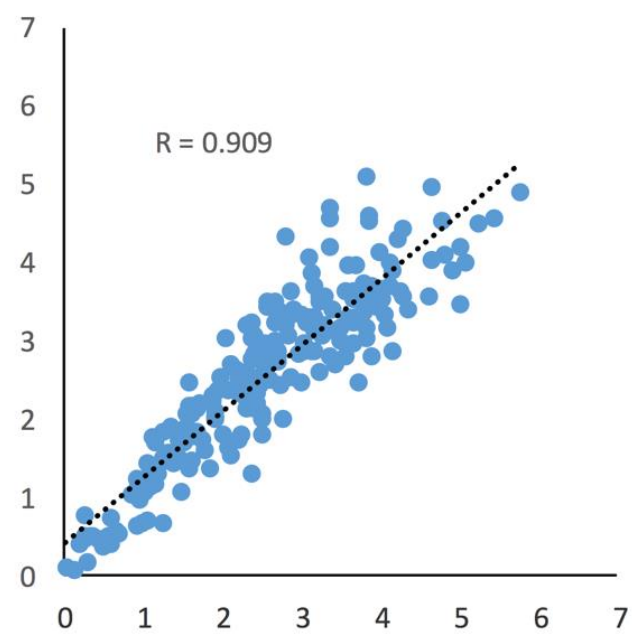

Fig. 4. Scatter chart of Model 2

Figure 3 is drawn to show the distribution of model 2 against Penman FAO 56 results and Figure 4 is the scatter chart of this model. It is possible to see the high relation between calculated and estimated results.

Model 3 is created by using air temperature and solar radiation meteorological variables as input. As it is seen from the figure 5 and figure 6 model results has less 
relation with Penman FAO 56 equation then the other two models results. Statistics belonging to models' results are given with Table 1.

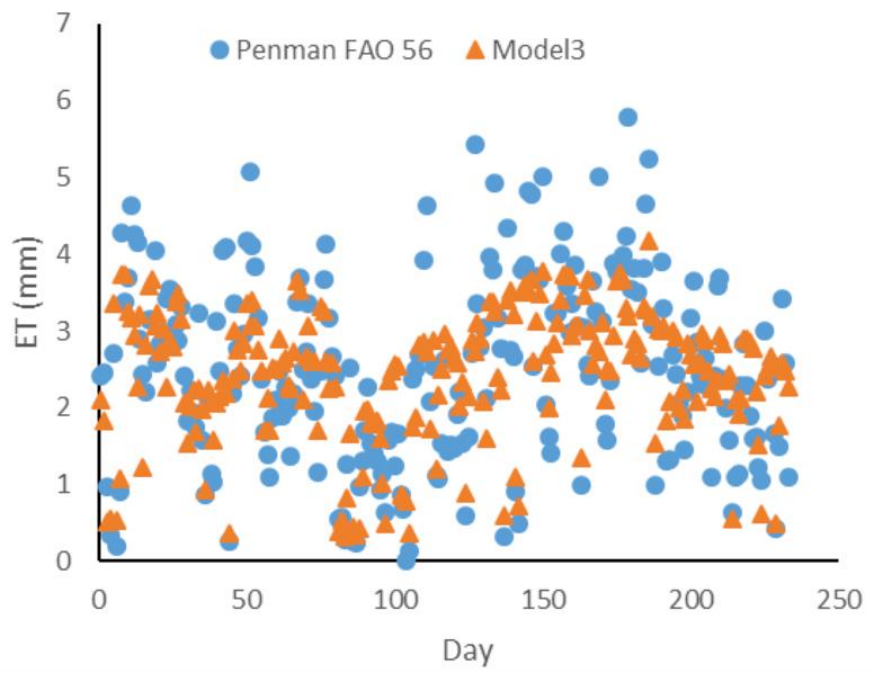

Fig. 5. Distribution graph of Model 3

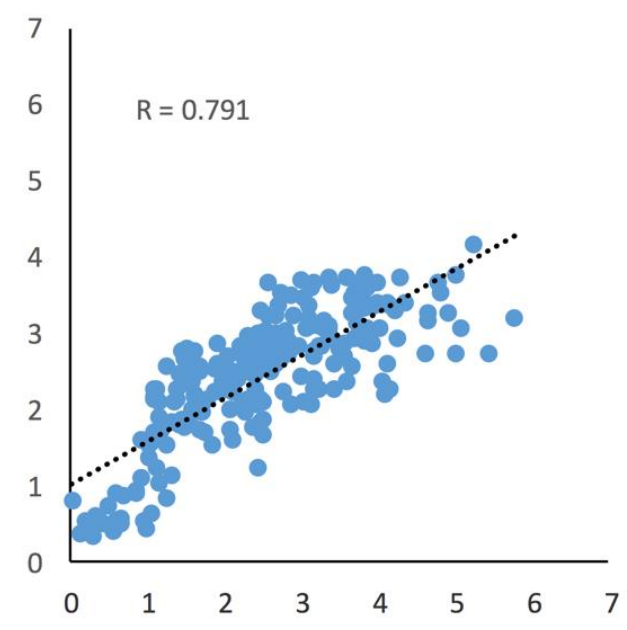

Fig. 6. Scatter chart of Model 3

\section{CONCLUSIONS}

In this study, three different adaptive neuro fuzzy inference system models are generated by using SR, T, U, RH meteorological variables. Models performances' are compared with each other by using MSE, MAE and correlation coefficient statistics. ET calculations are done by using Penman FAO 56 standard equation but, this equation needs all four meteorological daily parameters for 
calculation. However, it is not always possible to have all parameters recorded for a study area. Therefore, some other methods must be tried to estimate ET accurately as much as possible. In this study authors focused on using ANFIS on ET estimation for mentioned area.

Table 1. Comparison Statistics

\begin{tabular}{|c|c|c|c|c|}
\hline $\begin{array}{c}\text { ANFIS } \\
\text { Model No }\end{array}$ & $\begin{array}{c}\text { Parameters } \\
\text { Used }\end{array}$ & $\begin{array}{c}\text { Correlation } \\
\text { Coefficient }\end{array}$ & MSE & MAE \\
\hline 1 & T,SR,RH,U & 0.993 & 0.023 & 0.101 \\
\hline 2 & T, SR, RH & 0.909 & 0.251 & 0.391 \\
\hline 3 & T,SR & 0.791 & 0.551 & 0.576 \\
\hline
\end{tabular}

Model 1 estimation results are super close to Penman FAO 56 formula as it is expected. Model 2 performance shows that it gives quite close results to Model 1 performance and Penman FAO 56 equation even it is generated without wind speed parameter. Also, it is understood that, if only SR and T meteorological parameters are recorded for a studied area, results are still acceptable according to the Model 3 performance statistics.

\section{REFERENCES}

1. Chen, D.C. (2012) Daily Reference Evapotranspiration Estimation Based on Least Squares Support Vector Machines. Comput. Comput. Technol. Agric. V, Pt Ii 369, 54-63.

2. Demirci, M., Baltaci, A. (2013), Prediction of suspended sediment in river using fuzzy logic and multilinear regression approaches. Neural Computing and Applications, 23(1), 145-151.

3. Demirci, M., Unes, F., Saydemir, S. (2015a), Suspended sediment estimation using an artificial intelligence approach. Sediment Matters, Springer, 83-95.

4. Demirci, M., Üneş, F., Aköz, M.S. (2015b) Prediciton of cross-shore sandbar volumes using neural network approach. Journal of Marine Science and Technology, 20(1), 171-179.

5. Demirci, M., Taşar, B., Kaya, Y.Z. (2018a) Estimation of Groundwater Level Fluctuations Using Neuro-Fuzzy and Support Vector Regression Models. Int. J. Adv. Eng. Res. Sci. 5, 206-211. doi:10.22161/ijaers.5.12.29

6. Demirci, M., Üneş, F., Kaya, Y.Z., Tasar, B., Varçin, H. (2018b) Modeling Of Dam Reservoir Volume Using Adaptive Neuro Fuzzy Method, in: 10th International Water and Air Components Conference. Sovata, Romania, pp. 145-152.

7. Demirci, M., Unes, F., Akoz, M.S. (2016), Determination of nearshore sandbar crest depth using neural network approach. International Journal of Advanced Engineering Research and Science, 3(12), 133-140. 
8. Demirci, M., Unes, F., Kaya, Y.Z., Mamak, M., Tasar, B., Ispir, E. (2017), Estimation of Groundwater Level Using Artificial Neural Networks: a Case Study of HatayTurkey. 10th International Conference "Environmental Engineering".

9. Dogan, E. (2009) Reference Evapotranspiration Estimation Using Adaptive NeuroFuzzy Inference Systems. Irrig. Drain. doi:Doi 10.1002/Ird.445

10. Jang, J.R., (1993) ANFIS: Adaptive Network Based Fuzzy Inference System 23. doi:10.1109/21.256541

11. Jensen, M.E., Burman, R.D., Allen, R.G. (1990) Evapotranspiration and irrigation water requirements, ASCE Manuals and Reports on Engineering Practice No. 70.

12. Kaya, Y.Z., Mamak, M., Unes, F. (2016a) Evapotranspiration Prediction Using M5T Data Mining Method. Int. J. Adv. Eng. Res. Sci. 3, 225-229. doi:10.22161/ijaers/3.12.40

13. Kaya, Y.Z., Mamak, M., Ünes, F., Demirci, M. (2017) Evapotranspiration Prediction Using M5T Method and Ritchie Equation for St. Johns, FL, USA, in: Proceedings of 10th International Conference "Environmental Engineering." VGTU Technika, pp. 27-28. doi:10.3846/enviro.2017.024

14. Kaya, Y.Z., Üneş, F., Demirci, M., Tasar, B., Varçin, H. (2018) Groundwater Level Prediction Using Artificial Neural Network And M5 Tree Models, in: 10th International Water and Air Components Conference. Sovata, Romania, pp. 195-201.

15. Kaya, Y.Z., Üneş, F., Mamak, M. (2016b) Prediction of Evapotranspiration with Daily Meteorological Data Using M5 Model Tree, in: Book of Abstracts of the International Conference on Engineering and Natural Sciences (ICENS) 2016. Sarajevo, pp. 1976-1982.

16. Kim, S., Kim, H.S. (2008) Neural networks and genetic algorithm approach for nonlinear evaporation and evapotranspiration modeling. J. Hydrol. 351, 299-317. doi:10.1016/j.jhydrol.2007.12.014

17. Kisi, O. (2008) The potential of different ANN techniques in evapotranspiration modelling. Hydrol. Process. 22, 2449-2460. doi:10.1002/hyp.6837

18. Kişi, Ö. (2006) Generalized regression neural networks for evapotranspiration modelling. Hydrol. Sci. J. 51, 1092-1105. doi:10.1623/hysj.51.6.1092

19. Kumar, M., Raghuwanshi, N.S., Singh, R. (2011) Artificial neural networks approach in evapotranspiration modeling: A review. Irrig. Sci. 29, 11-25. doi:10.1007/s00271010-0230-8

20. Kutyłowska, M. (2016) Comparison of Two Types of Artificial Neural Networks for Predicting Failure Frequency of Water Conduits. Period. Polytech. Eng. 64, 1-6. doi:https://doi.org/10.3311/PPci.8737

21. Mamak, M., Üneş, F., Kaya, Y.Z., Demirci, M. (2017) Evapotranspiration Prediction Using Adaptive Neuro-Fuzzy Inference System and Penman FAO 56 Equation for St. Johns, FL, USA, in: Proccedings of 10th International Conference "Environmental Engineering." VGTU Technika, Vilnius, pp. 27-28. doi:10.3846/enviro.2017.085

22. Pal, M., Deswal, S. (2009) M5 model tree based modelling of reference evapotranspiration. Hydrol. Process. 23, 1437-1443. doi:10.1002/hyp.7266

23. Takagi, T., Sugeno, M. (1985) Fuzzy Identification of Systems and Its Applications to Modeling and Control. IEEE Trans. Syst. Man Cybern. SMC-15, 116-132. doi:10.1109/TSMC.1985.6313399

24. Talei, A., Hock, L., Chua, C., Quek, C., Jansson, P. (2013) Runoff forecasting using a Takagi - Sugeno neuro-fuzzy model with online learning. J. Hydrol. 488, 17-32. doi:10.1016/j.jhydrol.2013.02.022 
25. Taşar, B., Kaya, Y.Z., Varçin, H., Üneş, F., Demirci, M. (2017) Forecasting of Suspended Sediment in Rivers Using Artificial Neural Networks Approach. Int. J. Adv. Eng. Res. Sci. 4, 79-84. doi:10.22161/ijaers.4.12.14

26. Tasar B., Unes F., Demirci M., Kaya Y.Z. (2018), Yapay sinir ăglart yöntemi kullanılarak buharlaşma miktarı tahmini. DÜMF Mühendislik Dergisi, 9(1), 543-551.

27. Unes F. (2010a), Dam reservoir level modeling by neural network approach: a case study. Neural Network World, 4(10), 461.

28. Unes F. (2010b), Prediction of density flow plunging depth in dam reservoirs: an artificial neural network approach. Clean-Soil, Air, Water, 38(3), 296-308.

29. Unes, F., Demirci, M. (2015), Generalized Regression Neural Networks For Reservoir Level Modeling. International Journal of Advanced Computational Engineering and Networking, 3, 81- 84.

30. Unes, F., Yildirim, S., Cigizoglu, H.K., Coskun, H. (2013), Estimation of dam reservoir volume fluctuations using artificial neural network and support vector regression. Journal of Engineering Research, 1(3), 53-74.

31. Unes, F., Gumuscan, F.G., Demirci, M. (2017), Prediction of Dam Reservoir Volume Fluctuations Using Adaptive Neuro Fuzzy Approach. EJENS, 2(1), 144-148.

32. Üneş, F., Doğan, S., Taşar, B., Kaya, Y., Demirci, M. (2018b), The Evaluation and Comparison of Daily Reference Evapotranspiration with ANN and Empirical Methods. Natural and Engineering Sciences, 3(3), Supplement, 54-64.

33. Üneş, F., Demirci, M., Mertcan, Z., Taşar, B., Varçin, H., Ziya, Y. (2018c). Determination of Groundwater Level Fluctuations by Artificial Neural Networks. Natural and Engineering Sciences, 3(3), Supplement, 35-42.

34. Üneş, F., Bölük, O., Kaya, Y.Z., Taşar, B., Varçin, H. (2018a) Estimation of RainfallRunoff Relationship Using Artificial Neural Network Models for Muskegon Basin. Int. J. Adv. Eng. Res. Sci. 6, 198-205. doi:10.22161/ijaers.5.12.28

35. Üneş, F., Demirci, M., Kişi, Ö. (2015a) Prediction of millers ferry dam reservoir level in USA using artificial neural network. Period. Polytech. Civ. Eng. 59, 309-318. doi:10.3311/PPci.7379

36. Üneş, F., Joksimovic, D., Kisi, O. (2015b) Plunging Flow Depth Estimation in a Stratified Dam Reservoir Using Neuro-Fuzzy Technique. Water Resour. Manag. doi:10.1007/s11269-015-0978-y

37. Ünes, F., Kaya, Y.Z., Mamak, M., Demirci, M. (2017) Evapotranspiration Estimation Using Support Vector Machines and Hargreaves-Samani Equation for St. Johns, FL, USA, in: Proccedings of 10th International Conference "Environmental Engineering." VGTU Technika, pp. 27-28. doi:10.3846/enviro.2017.094

38. Yu, P.S., Chen, S.T., Chang, I.F. (2006) Support vector regression for real-time flood stage forecasting. J. Hydrol. 328, 704-716. doi:10.1016/j.jhydrol.2006.01.021 